\title{
Farmers' Income through Cassava-based Food Diversification
}

\author{
Sri Wiyati Mahrani ${ }^{1}$ Rormawaty ${ }^{2}$ Yusuf Montundu ${ }^{3}$ \\ Eliyanti A. Mokodompit ${ }^{4}$ Yusuf ${ }^{5}$ Arman Alimuddin 6 \\ 1,3,4,5,6 Department of Management, Halu Oleo University, Southeast Sulawesi Indonesia \\ ${ }^{2}$ Department of Agriculture, Halu Ole Halu Oleo University, Southeast Sulawesi Indonesia
}

\begin{abstract}
The purpose of this study was to describe the stages of processing cassava into kaopi. Analyze the farmers' income through diversification of cassava-based food (processing cassava into kaopi). Analyze the value-added of food diversification based of cassava. Respondents of this study were farmers who undertake the processing of cassava into kaopi determined by simple random sampling of 31 people. Data were obtained through direct interviews and analyzed using qualitative descriptive analysis, analysis of revenue and value-added analysis. The results showed that the processing of cassava into kaopi through stages: (1) stripping the skin potato logs, (2) washing, (3) grate, (4) cleaning, (5) stamping and (6) packaging. The income received by farmers through diversification of cassava-based food.
\end{abstract}

Keywords: Income, Food Diversification, Cassava

Date of Submission: 10 November $2016 \longrightarrow$ Date of Accepted: 05 December 2016

\section{INTRODUCTION}

Food endurance is a strategic importance because it is a basic requirement and the essence of human life, and therefore the right to food is very important from the human rights (Krisnamurti, 2006). Kaopi is processed cassava products in the form of semi-finished shredded then placed in a container that is then pressed until dry sack. Kaopi has a fairly complete nutritional content. Kaopi nutritional composition consisting of water $(33.28 \%)$, protein $(0.52 \%)$, carbohydrates $(65.03 \%)$, fat $(0.09 \%)$, vitamin C $(5.46 \mathrm{mg})$ and ash $(1,08 \%)$. In addition kaopi calories are quite high at $270.10 \mathrm{Cal} /$ gram. Processing results in the form kaopi can be used into various comestible typical in the district Batauga Buton like: kasuami, sinole, lanta, onde-onde, deaf-mutes, sea cucumbers, EPU-EPU, doko-doko, sanggara banda and crackers while cassava without processing can only be boiled and then consumed. Processing of cassava in districts Batauga has developed into one of the centers of processing cassava into kaopi because it is supported by the geographical conditions suitable for the cultivation of cassava. Production of cassava plants amounting to 4,438 tons per year with the planting area of 420 hectares.

One group of farmers who cultivate cassava is Uwe Magari farmer groups. The group supplies the raw material for making kaopi of the crop farmer group itself. Production of cassava that can be generated by farmer groups Uwe Magari the first time planting period (1 year up to 2 times MT) is $500 \mathrm{~kg}$ to $600 \mathrm{~kg}$ of potato $\operatorname{logs}$, the price is very volatile, ranging between $\mathrm{Rp} \mathrm{3,500} \mathrm{-} \mathrm{Rp} \mathrm{5,000} \mathrm{per} \mathrm{kg}$. The results are for sale on traders and partly sold on cassava processing unit group (kaopi). But often face obstacles in the form of income or experience erratic fluctuations in each month. This condition occurs because it is influenced by a number of uncertain market demands in each month, which is due to the products sold in traditional markets where market demand depends on buyers coming from surrounding areas.

Furthermore, there are groups of cassava processing (kaopi) consisting of 5 people consisting of cassava farmers wives are also housed in the village Laompo. For now the group only produced and marketed in the District kaopi Batauga and surrounding areas. Cassava raw material obtained from farmer groups Uwe Magari, while other materials can be purchased around the mills. Farmer groups have not dared to undertake production on a large scale because it is hampered by several problems, including not have the capital to purchase equipment that is hygienic, not have access to adequate market and also does not have the books are good, so that the group has not been able to determine exactly the benefits received when manufacture of processed cassava (kaopi) on a large scale.

Processing cassava into kaopi used raw materials of approximately 14.5 kilograms of raw material yield 1 kaopi pack in 1 package kaopi and an average of 5.5 kilograms. Kaopi price of Rp 25,000 - Rp 30,000 per bale when converted into units of kilogram to $\mathrm{Rp} 4,800$ - $\mathrm{Rp} 5,000$. The average price of raw materials $\mathrm{Rp}$ 800 per kilogram is the price of potato logs. The amount of value added which is formed of the processing activity is influenced by the level of technology used and the treatments given to the raw material is processed. Processing of cassava into kaopi by farmers, used the technology of manual and semi-mechanical. 
Through this study expected to address the issue of income fluctuated in the group of farmers a result of uncertain market demand and to increase the production, market share and good management on cassava processing unit group (kaopi). Thus will be able to increase revenue for the group members' cassava farmers and processors (Kaopi) in the village of Laompo

\section{LITERATURE REVIEW}

Food diversification is an election process that is not dependent on any one type of food but a variety of food ranging aspects of production, processing aspects, distribution aspects to aspects of food consumption at the household level (Tampubolon, 1998). Lawal and Jaiyeola, (2007) opined that value addition improves the shelf life of agricultural products and generates income for participants. Since most government interventions and policies are aimed at integrating the rural poor into the mainstream of the economy, one of the ways of achieving this is by adding value to their produce. The evaluation of the present state of small scale cassava processing is therefore imperative. In order to tap the full potential that cassava presents there is therefore the need for a study on value addition to cassava and the factors that are likely to influence value addition so that rural communities whose livelihoods depend on it will benefit from the present traditional food market and new emerging markets.

\section{METHODOLOGY}

The method will be used in this program are:

1. Method of Technology Transfer. This model is used to help the domestic industry effort kaopi to cultivate and develop production through the application of appropriate technology that is readily available, easily operated and inexpensively so that it can be reached by adopting the production of good food (CPMB) The production process kaopi that will be given are control techniques quality products ranging from raw materials to finished products and packaging.

2. Method of entrepreneurship capacity building (ECB), which is helping home business industry kaopi in shaping the entrepreneurial spirit that is professional, both in technical and in the management of the management.

Work procedures to support the realization of the offered method are as follows:

1. Aspects of production

a. Selection of business groups that will be involved

Farmer groups will be trained in this program there are 2 farmer groups in the village of Magari Uwe Laompo Buton as providers of raw material cassava and cassava processing group (kaopi) as producer Laompo kaopi in the village of Buton.

b. Selection of raw materials and equipment used

c. Technology transfer in both business groups

In the implementation of the cassava processing (kaopi) will remain the manufacturing technology uses a simple, but needs to be improved is the quality control of products ranging from the selection of raw materials, processing to the packaging.

2. From the aspect of management that will be conducted as follows:

a. Collect and board members of farmer group "light farmer" and "Uwe Magari" which will be given technical guidance bookkeeping

b. Provide and gives examples of charging daily cash books, book inventory and how to prepare financial statements especially income statement.

\section{ANALYSIS AND RESULT}

A community service activity is carried out in the village of Buton Laompo South. IbM activity is intended to solve the problems of partners (production and management issues). The dedication is done in the form of training and practice of appropriate technology, which is followed by 10 people consisting of 5 people from the business group Uwe Magari and 5 people from the business group Sinar Tani. The method used is the method of transfer of technology (technology transfer) and methods of entrepreneurship Capacity Building (ECB). In the implementation of processing activities will continue to use the technology of making simple, but needs to be improved is the quality control of products ranging selection of raw materials, processing to packaging. During this time the resulting product is not maximized because of the unavailability of press tools and machines grate. Based on the problems that have been identified, it has carried out the steps the completion of the form:

Socialization activities

Promoting the activities carried out to group members Uwe Magari businesses and business groups Sinar Tani (Figure 1), with the aim that the partners have the same goal to improve the quality and market share kaopi and management capabilities. In addition to socializing with both partners also conducted socialization to the relevant government agencies and other stakeholders. The goal is that the local government / village joined monitor and motivate the citizens to continue to develop its business. 


\section{A. Preparation Training}

Procurement of equipment and training equipment and supplies training has been prepared. The equipment is stripping and cleaning equipment, scraping, rafting, pressing and packaging. Grated machines and pressing tools handed over by the two business groups Uwe Magari and Sinar Tani targeted program.

Preparation of training places, business management and technical training to improve the quality kaopi carried out at the site of Uwe Magari business group in the village Laompo Batauga Buton District of South.

\section{B. Implementation of Training}

Activities of business management training and technical quality improvement kaopi held on August 20, 2015 in the business group Uwe Magari village Laompo District of Batauga Buton South followed by 10 people consisting of 5 people from the business group Uwe Magari and 5 people from the business group Sinar Tani. The training materials were given starting with the introduction of raw material, cassava processing and packaging.

\section{Evaluation of Technical Training and Business Management}

To know the development and implementation of technical training and business management views of liveliness and seriousness of the participants attended the training. In general it can be reported that the enthusiasm of partner groups participated in high enough that indicated quite a lot of participants who are interested in asking a lot of good questions about aspects of production and management aspects.

Technical guidance aspects of production such as: Repair facilities and tools that do not qualify management of healthy food, container repair and replacement tool presses more hygienic. The results achieved by increasing the production capacity of raw materials used by the machine shredded and pressed the new tool. During this time they have not had a shredded engine itself and to grate cassava they rent at a cost of Rp. 5.000, - per pack kaopi.While aspects of the management after training technique of making financial records such as: book daily cash is recorded cash inflows and outflows, raw material inventory and budgets raw materials are aimed to know the quantity of raw materials used and the quantity of raw materials to be purchased during the specified period, knowing the price of raw materials, so it can be used as guidelines for the purchase price of raw materials, know the amount of the monetary unit of raw material to be purchased are on a budget as well as the raw materials to maintain smooth production.

Provide training on the preparation of Financial Statements consisting of Balance report and Profit and Loss report. Process of mentoring (guiding, supervising and evaluating) to post IbM activity results achieved by increasing the knowledge of both groups of partners on daily cash book production, inventory and financial statements. Besides it has provided daily cash book, inventory and financial statements.

\section{CONCLUSION}

From the description of the method of implementation and the discussion it can be concluded as follows:

1. Procurement of equipment is more hygienic to increase production kaopi

2. Repair and appearance of packaging can improve sales turnover

3. The capacity of the group members in business management increased

With the positive public response to the activities of science and technology to the Community is done, it is expected that the community will be more active and in response to the application of post harvest technology is mainly related to the processing of cassava so as to increase their income

\section{FUTURE RESEARCH}

For further research needs to carry out the development of this research for improving the income of farmers through cassava processing needs to be done regularly and continuously, because with a good understanding of the importance of agro-processing, the people will be motivated to do so.

\section{REFERENCES}

[1] Asmiati, 2012. Analisis Nilai Tambah Pengolahan Ubi Kayu di Kecamatan Batauga Kabupaten Buton. Skripsi Jurusan Agribisnis Universitas Haluoleo. Kendari (tidak dipublikasikan)

[2] BP3K Kecamatan Batauga. 2011. Varietas Ubi Kayu. Batauga

[3] Wijanarko, R. D. T., Assayuthi M., Amalia U., dan Dian D. 2012. Uji Kadar Protein dan Lemak pada Kasoami Dengan Beberapa Perlakuan. Makalah Dalam Seminar Nasional Kemandirian Pangan, 11-12 Juli 2012. Balai Pengkajian Teknologi Pertanian Jawa Barat, Fakultas Teknologi Industri Pertanian Universitas Padjajaran dan Dewan Riset Daerah Jawa Barat. Bandung. 
[4] Zani M, Rosmawaty, dan Yusria W 2012. Analisis Pendapatan Petani Melalui Diversifikasi Pangan Berbasis Ubi Kayu di Kabupaten Buton. Laporan Hasil Penelitian Dosen Pemula Bidang Ketahanan Pangan,

[5] Rosmawaty, dkk, 2015. Pengolahan Kripik Singkong Aneka Rasa Berbasis Pangan Lokal di Kabupaten Konawe Selatan. Prosiding Seminar Nasional Swasembada Pangan. 9 Maret 2015. Unhalu Press. 